\title{
The Supply Chain and Logistics of Vietnam in the Context of International Economic Integration
}

\author{
Pham Nguyen My Linh ${ }^{1}, \&$ Nguyen Thi Thu Huong ${ }^{2}$ \\ ${ }^{1}$ Asper School of Business, University of Manitoba, Manitoba, Canada \\ ${ }^{2}$ Academy of Finance, Hanoi, Vietnam \\ Correspondence: Pham Nguyen My Linh, Asper School of Business, University of Manitoba, Manitoba, Canada.
}

Received: April 30, 2020

doi:10.5539/ibr.v13n7p27

\begin{abstract}
Nowadays, in the current economy of Vietnam, logistics plays an important role in production and business activities of many enterprises, citizens and as well as the entire operation in the economy. However, logistics in Vietnam is still at a low level of development, which has not fully promoted the role of linking economic entities and activities in the national economy system. Therefore, logistics development is an urgent issue for policy makers as well as enterprises. This paper focuses on analyzing the status of logistics development in Vietnam, showing the results, limitations and causes of logistics development in Vietnam, thereby proposing some recommendations for development in the context of international economic integration.
\end{abstract}

Keywords: development, logistics, Vietnam

\section{Introduction}

In a market economy, logistics is the connection and cooperation, therefore, it plays an increasingly important role and is an indispensable factor in the production, distribution and circulation of goods, especially in creating beneficial business environment to improve the efficiency of production and business activities in all fields. Vietnam has many favorable conditions to develop the logistics industry thanks to its geography. Vietnam is located in a strategic position of the region, long stretching coast, which have many sea ports, international airports, road systems, transnational railways, economic corridors. Besides, with the participation of WTO, AEC, Vietnam has become an open country for trading, goods, services and investment, with many opportunities to access the vast markets of the region and the world with trade incentives such as: reduction of tariffs and non-taxes, application of MFN, NT and GSP regulations for products and services. Vietnam also has many opportunities to access the latest scientific and technological achievements, advanced management methods of the world, and logistics activities in Vietnam have been paid more attention by the management at central, local level and businesses. However, enterprises specializing in providing logistics services only meet part of the needs of the domestic market, have not yet reached the regional and international markets. All the conditions of infrastructures for the development of this service in Vietnam are very limited. Since Vietnam has become a member of the World Trade Organization and the Comprehensive and Progressive Agreement for Trans-Pacific Partnership (CPTPP), logistics development in the economy in general as well as logistics activities of Vietnamese enterprises in particular are facing new opportunities and challenges, which require a clear awareness of the role of this activity in both theory and practice. Originating from the reality, we would like to share our views on assessing the current situation of logistics development in Vietnam and suggest some scientific and practical recommendations on this issue.

\section{Literature Review}

The natural resources on earth are finite, but human desires are immensely. Therefore, logistics was born to help people use resources (human, material and financial resources) optimally to meet the increasing demands of themselves and society in the best way (Doan Thi Hong Van, 2003). The research by Ronald Hballou, Stephen Mgilbert, Ashok, Yukherjee (2000) suggests that supply chain is an emerging term that emphasizes the interaction between marketing, logistics and production. With this terminology and its application, the opportunity is primarily relevant to the management of logistics channels that transcend the legal boundaries of businesses. Supply chain management has brought us from an internal vision of the channel to an interface and 
even an inter-organization. Focusing on inherent issues in inter-organizational management, as this is where traditional management tools and techniques are no longer appropriate. The research by Dang Dinh Dao, Ta Van Loi, Nguyen Minh Son and Dang Thi Thuy Hang (2019) identified logistics as the process of distributing and circulating goods organized and logically managed. The planning, organizing, implementing and controlling the process of goods and service flow from the starting point of production to the end-consumer hands at the lowest cost to ensure the smooth and seamless process of social production and procedures and at the same time satisfy the demands of customers.

Today, one of the main functions of logistics is to distribute the flow of raw materials from the manufacturers to the consumers. Modern scientific methods focus on many tasks at different stages of the logistics system. However, the interaction effectiveness of logistics systems is in isolation and does not consider issues that improve the efficiency of society as a whole. Meanwhile, there is a link between the costs of commercial organizations, industrial enterprises and consumers. This leads to the need to take into account the consumer composition of the logistics system. The development of a logistics method based on consumers' profits and losses, which opens up new opportunities to improve the service and efficiency of the logistics system (AndriiGalkin, ConstantinDolia, NataliiaDavidich, 2017).

The research of Anthony Roath, Judith Whipple, Stanley E. Fawcett (2013) shows that supply chain management is developing rapidly because of both strategic initiative and discipline. As companies increasingly include their supply chain partners in developing business strategies, researchers will have to constantly re-evaluate basic topics and emerging theories of logistics strategies, management and marketing by introducing new topics and reviewing expansion results. In the modern business scenario, the supply chain has become the backbone of all business organizations. All supply chain partners are united in the company's value distribution network, which no one could have done better without the support of others. The ultimate goal of this close relationship is to bring value to the customers and achieve the desired state of customer satisfaction \& loyalty towards the organization. With this purpose, it is necessary to integrate supply chain and internal partners at different levels. The structure of supply chain integration has been divided into three sections: information integration, shared resources and organizational relationship links (Raja Irfan Sabir; Muhammad Irfan, 2014). R. Glenn Richey, Haozhe Chen, Stanley E. Fawcett, (2009). Therefore, this shows that implementing supply chain management techniques requires thorough integration of processes among supply chain partners in all functional areas, including sourcing, manufacturing and distribution. Outsourced logistics services have been established in the field of LSP (Logistics Services Provider), which provides a range of services to its customers. In particular, transport is one of the most important services, and therefore effective fleet management is essential to establishing a high level of customer service. With the improvement in vehicle tracking technology and systems, this management approach has gained new capabilities to improve logistics (Mauro VivaldiniI; Silvio R.I.PiresI; Fernando Bernardi de SouzaII, 2012).

Research by Dang Dinh Dao (2011) said that logistics services along with information technology, financial services, business support services and education services which are considered as "infrastructure services" in the national economy, play an important role in developing the growth model and restructuring the economy, improving quality, efficiency, rapid development and economic sustainability. Since ports are important hubs in the logistics chain, they play a decisive role in improving the efficiency of the logistics process. The goal of port logistics is to focus on building port services areas to optimize the logistics process by improving port compatibility in the logistics chain (Nguyen Thanh Thuy, 2009).

In an era of increasing globalization, the logistics industry is gradually becoming a unique element and a source of international competitiveness. However, it now requires a stimulating legal environment instead of constraining efficiency and competitiveness. Singapore's logistics policies are the basis for policymakers to consider in improving the competitiveness of the national logistics industry (Jose L. Tongzon, 2018). The law on logistics services has a profound impact on e-commerce activities in Vietnam. Therefore, the State should take appropriate measures to complete and improve the effectiveness of the enforcement of logistics laws in e-commerce (Ta Thi Thuy Trang, 2018). Research by Nguyen Tuong, Dao Trong Khoa (2018) stated that LPI allows governments, businesses and related parties to assess the competitive advantages created by the positive results of logistics activities, and to take measures to solutions to improve logistics - the backbone of the global economy. The components analyzed in international LPI are based on theoretical, empirical research and based on the practical experience of logistics specialists involved in international freight forwarding, includes: The efficiency of customs and border management clearance ("Customs"); the quality of trade and transport infrastructure ("Infrastructure"); the ease of arranging shipments with competitive prices ("Ease of arranging shipments"); the competence and quality of logistics services - trucking, forwarding, and customs brokerage ("Quality of logistics services"); the ability to track and trace consignments ("Tracking and tracing") and the frequency with which shipments reach 
consignees within scheduled or expected delivery times ("Timeliness") (World Bank).

\section{Method}

We mainly use descriptive statistical methods to analyze reality, results and limit the situation of logistics development in Vietnam. Data is collected and synthesized from the General Statistics Office of Vietnam over the years, Vietnam Logistics Report 2019, Documentation of Logistics Performance Index (LPI) - Ministry of Industry and Trade of Vietnam, Short report of Vietnam Logistics Business Association (VLA), International LPI of World Bank.

\section{The Current Situation of Logistics Development in Vietnam}

\subsection{Actual Situation of Goods Supply of Vietnamese Economy}

Over the past few years, the logistics system in Vietnamese economy has contributed to ensure the supply of goods and services of the economy, meet the requirements of society, organizations, businesses and consumers. Goods and services circulating in the market are increasingly rich and diverse in types, improving in quality, meeting consumers' demands. Out of the total retail sales of goods and services, social consumption (Table 1): The average retail accounted for $74.9 \%$, accommodation, catering accounted for $12.3 \%$ and services and tourism accounted for nearly $12.8 \%$.

Table 1. Total retail sales of goods and services at actual prices by business lines of Vietnam (2015 - 2018)

Unit: VND billion

\begin{tabular}{|c|c|c|c|c|c|}
\hline & Year & Total & Retail & $\begin{array}{c}\text { Accommodation service, food and } \\
\text { drink }\end{array}$ & $\begin{array}{c}\text { Services and } \\
\text { tourism }\end{array}$ \\
\hline \multirow{4}{*}{$\begin{array}{l}\text { Value } \\
\text { Billion) }\end{array}$} & 2015 & $3,223,202.6$ & $2,403,723.2$ & $399,841.8$ & $419,637.6$ \\
\hline & 2016 & $3,546,268.6$ & $2,648,856.7$ & $439,892.2$ & $457,519.6$ \\
\hline & 2017 & $3,956,599.1$ & $2,967,484.7$ & $488,615.6$ & $500,498.8$ \\
\hline & $\begin{array}{l}\text { Preliminary } \\
2018\end{array}$ & $4,416,620.7$ & $3,329,049.0$ & $534,175.7$ & $553,396.0$ \\
\hline \multirow[t]{4}{*}{ Structure (\%) } & 2015 & 100.0 & 74.6 & 12.4 & 13.0 \\
\hline & 2016 & 100.0 & 74.7 & 12.4 & 12.9 \\
\hline & 2017 & 100.0 & 75.0 & 12.3 & 12.7 \\
\hline & $\begin{array}{l}\text { Preliminary } \\
2018\end{array}$ & 100.0 & 75.4 & 12.1 & 12.5 \\
\hline
\end{tabular}

Source: General Statistics Office of Vietnam

Table 2. The total flow of import and export goods of Vietnam (2015 - 2018)

Unit: Million USD

\begin{tabular}{lcccc}
\hline & Total & Export & $\begin{array}{c}\text { Import } \\
(* *)\end{array}$ & Symmetrical $(*)$ \\
\hline Value (Million USD) & & & & \\
2015 & $327.792,6$ & $162.016,7$ & $165.775,9$ & $-3.759,2$ \\
2016 & $351.559,2$ & $176.580,8$ & $174.978,4$ & $1.602,4$ \\
2017 & $428.333,9$ & $215.118,6$ & $213.215,3$ & $2.915,4$ \\
Preliminary 2018 & $480.879,3$ & $243.697,3$ & $237.182,0$ &.. \\
Development index (Previous year = 100)-\% & & & &. \\
2015 & 110,0 & 107,9 & 112,1 &. \\
2016 & 107,3 & 109,0 & 105,6 &. \\
2017 & 121,8 & 121,8 & 121,9 &. \\
Preliminary 2018 & 112,3 & 113,3 & 111,2 &. \\
\hline
\end{tabular}

Source: General Statistics Office of Vietnam 
The supply network is expanded in three areas: urban, rural and mountainous areas, with the participation of business entities. Organization and business methods - buying and selling methods become more innovative, richer and more flexible.

The situation of ensuring the supply of goods is also reflected through the import and export activities of the economy, especially in ensuring goods for export and organizing import activities to meet production and consumption needs in the country. In the period of 2015 - 2018, import-export activities achieved many encouraging results, with the average growth rate of total import and export of goods reached $112.85 \%$, of which the growth rate of the total turnover of exported goods averaged $113 \%$ and imports averaged $112.7 \%$ (Table 2).

\subsection{Current Situation of Consumers' Demand / Use of Logistics Services in Vietnam}

Businesses need the most basic logistics activities to carry out their production and business activities. According to the Vietnam Logistics Report 2019, the percentage of outsourcing and self-implementing logistics services is the same $(50 \%-50 \%)$. Specifically, the proportion of outsourcing logistics services of enterprises participating in the survey is shown in Table 3.

Table 3. Proportion of outsourced services of Vietnamese enterprises

\begin{tabular}{|c|c|c|c|c|c|c|}
\hline No. & Services & $\mathbf{0 \%}$ & $1-25 \%$ & $26-50 \%$ & $51-75 \%$ & $76-100 \%$ \\
\hline 1. & Inland transport & $2,6 \%$ & $13,6 \%$ & $18,6 \%$ & $23,1 \%$ & $14,3 \%$ \\
\hline 2. & Shipping goods in the country & $13 \%$ & $19,7 \%$ & $13,4 \%$ & $10,8 \%$ & $3,6 \%$ \\
\hline 3. & $\begin{array}{l}\text { International transportation (including international freight } \\
\text { shipping) }\end{array}$ & $9,1 \%$ & $6,8 \%$ & $17,5 \%$ & $18,5 \%$ & $42,9 \%$ \\
\hline 4. & Warehouse management and inventory & $10,4 \%$ & $16,7 \%$ & $13,4 \%$ & $20 \%$ & $3,6 \%$ \\
\hline 5. & $\begin{array}{l}\text { Value-added services such as product completion and tuning for } \\
\text { each customer }\end{array}$ & $23,4 \%$ & $13,6 \%$ & $12,4 \%$ & $13,8 \%$ & $0 \%$ \\
\hline 6. & Logistics information technology system & $18,2 \%$ & $15,9 \%$ & $14,4 \%$ & $4,6 \%$ & $17,9 \%$ \\
\hline 7. & Customs broker & $23,4 \%$ & $13,6 \%$ & $10,3 \%$ & $9,2 \%$ & $17,9 \%$ \\
\hline
\end{tabular}

Source: Vietnam logistics report 2019

We can see that the general trend is visible: firms mainly outsource international transport (nearly half of surveyed firms outsource the majority of 76-100\%), followed by inland transport and warehousing $(23,1 \%$ and $20 \%$ of enterprises outsource from $51-75 \%$ ). Less outsourced activities are value added, customs and domestic forwarding activities. IT logistics activities are difficult to evaluate because the amount of outsourcing is quite uniform, except for the number of outsourced businesses from $51-75 \%$ accounting for only $4.6 \%$ of businesses participating in the survey. When businesses outsource logistics services, most businesses have supplier assessment activities, and there are agreements at different levels.

\subsection{Actual Situation of Vietnamese Supply Chain Management and Logistics}

\section{Overview of Vietnamese logistics service market}

About market size: The logistics market increases with commercial demand, including domestic trade, import and export. In addition, the increase in outsourcing logistics also contributes to the development of the industry. Vietnamese retail industry has a relatively high growth rate. Vietnam is a country with a high population density, a young population, a rapid urbanization, an increase in per capita income and a high proportion of consumers using mobile and spending more time online than neighboring countries, accessible and online shopping. These are factors that promote the demand side of logistics services. The demand for goods flow to serve consumers is increasing.

Especially, e-commerce has been developed, increased demand for shipping services. Developing e-commerce will help manufacturers to have more domestic and international goods distribution channels, ship products directly to consumers. The demand for fast delivery and quality assurance is becoming a competitive standard for retailers. Tracking products shipped on mobile devices, managing smart commercial ads and cloud storage of large amounts of products information are initiatives that can be achieved. Major achievements in the field of e-commerce services, including supply chain and logistics. Import and export continue to grow with the turnover in the first 6 months of 2019 increased rapidly, compared to the same period in 2018. This boosted the demand for logistics in import and export activities such as multimodal international goods transport, container transport; trucking domestic transport; system of warehouses, yards and bonded warehouses and customs procedures.

According to VLA's survey, the rate of outsourcing logistics services of domestic manufacturing and trading 
enterprises is about 60 to 70 percent. However, by summarizing and evaluating through some practical research, results and surveys, it can be seen that Vietnamese logistics outsourcing market is quite vibrant, a young market but has great growth potentials. Businesses tend to increase the proportion of outsourcing logistics services to focus on the main production and business sectors, reduce investment capital and reduce costs, help improve customer service quality, mobilize products and increase access to the market. The relocation of facilities of many foreign enterprises to Vietnam is and will create great demands for the service market. Moreover, this create great opportunities for building a logistics warehouse network. At the same time, there is also pressure from increasing demands from customers, especially requirements for services that meet international standards (Vietnam Association of Logistics Services Enterprises, 2019).

About the number of enterprises participating in the market: According to the National Enterprise Registration Database, as of the end of March 2018, the whole country had 296,469 enterprises registering for businesses in logistics-related fields, focusing mainly on the region which has convenient ports and road system such as: Red River Delta (38.8\%), Southeast (33.8\%), North Central and Central Coast (14.2\%), Midlands and Northern mountainous region (5.6\%), Mekong River Delta (5.2\%), Central Highlands (2.4\%) (Hoai Anh, 2018).

About the size of the business: The scale of registered capital of logistics enterprises is very limited, up to $90 \%$ of the registered enterprises have capital of less than 10 billion VND. According to the Vietnam Association of Logistics Services Businesses (VLA), the growth of logistics industry in Vietnam in recent years has reached about $14-16$ percent, with a scale of about 40 - 42 billion USD per year. Joining the logistics market includes about 3,000 domestic enterprises and about 25 leading logistics corporations in the world to do business in various forms. Currently, many transnational logistics service providers are operating in Vietnam with big names such as DHL, FedEx, Maersk Logistics, APL Logistics, CJ Logistics, KMTC Logistics, etc. (Business Associations Logistics service enterprises, 2019). In particular, there has been a boom in e-commerce and e-logistics recently. According to the Department of E-Commerce and Digital Economy (Ministry of Industry and Trade), e-commerce grows to 35 percent a year. The e-commerce retail sales in the period 2016 to 2020 is estimated to increase by $20 \%$ per year and the total sales of Vietnam is expected to reach 10 billion USD by 2020 (Bach Hue, 2019). Changes in e-commerce in the world and in Vietnam have motivated Vietnamese logistics industry to improve the method of providing services in a more professional and effective way.

On the level of development of service delivery types: The mode of providing third party logistics services - 3PL continues to be the most popular mode of supply and has an important impact on the chain. However, the number of enterprises providing this method only accounts for about 16 percent and is mainly foreign-invested enterprises. Foreign logistics enterprises operate in Vietnam in many forms, especially in providing 3PL services with modern and professional technology level as in developed countries. Some businesses are gradually implementing the 4PL and 5PL models on the basis of developing modern, efficient and professional e-commerce and supply chain management. Besides, domestic logistics businesses are also constantly developing to provide more comprehensive package of logistics services. Since the majority of businesses only provide a number of services in the logistics chain, up to now, domestic logistics have gained the trust from shippers. According to VLA's statistics, currently 52.8 percent of shippers choose domestic logistics companies. In most areas of port operation, warehousing, inland road transport, inland waterway transport and domestic enterprises are dominating. Vietnamese businesses own most of their warehouses, so foreign businesses have to sublease, associate or enter into joint ventures to serve logistics services. In addition, big domestic companies such as Gemadept, Transimex, Vinatrans, etc. are also aiming at integrated and comprehensive logistics services, operating under the 3PL model to boost production, business development through cost optimization and added value for goods and services of the business. In order to join the 3PL model, domestic businesses tend to invest in logistics infrastructures, especially in warehouses or logistics distribution centers. However, the main logistics services that domestic enterprises provide to customers are still warehousing, freight transport, freight forwarding, loading and unloading, sorting services, packaging, warehousing and other services in the logistisc service chain. Although there are some suppliers, there are not a lot and they have not really been interested in developing. In addition, a trend of 2019 is the significant increase in logistics services for e-commerce. The number of companies participating in last-mile delivery for e-commerce has increased rapidly, especially for bulk, value-added and food and beverage commerce (Logistics Service Business Association Vietnam, 2019).

In general, the quality of logistics services in Vietnam has been significantly changing in the past few years, in which, the infrastructure of trade - transportation, telecommunications and information technology as well as the quality of logistics services from the private sector are rapidly improving.

Scope of operation and capacity to provide services: In 2018 and 2019, transportation, warehousing, shipping and other related services all experienced positive growth. Although the number is big and tends to increase 
compared to the accession of foreign logistics enterprises, most of Vietnamese logistisc enterprises are still small and medium enterprises in terms of capital, labor and technology. The financial potential of Vietnamese logistics enterprises is modest ( 80 percent of established enterprises have registered capital of 1.5 to 2 billion VND). Besides capital problems, they still lack of experiences and are limited in competitiveness, therefore, they have not had the opportunity to reach the market with great demand. In addition, there is a lack of synchronous linkages between businesses, between different stages of logistics activities (Vietnam Logistics Report, 2019).

In addition, human resources is also an obstacle, because most of the current human resources in Vietnam are trained from various sources, not yet formally and properly trained. The capacity of Vietnamese logistics enterprises is therefore limited by the quality of staff not meeting the demand. Among domestic businesses, up to 93 to 95 percent of workers are not trained in logistics, mainly doing services in smaller supply chains such as shipping, warehousing, handling bill of lading, etc. The labor force of logistics enterprises in Vietnam is quite small, enterprises with less than 50 employees account for about 32.4 percent and large-scale enterprises (over 1,000 employees) account for a small proportion of only about 10.8 percent. On the other hand, apart from the important factor human being, technology is a key competitive advantage in this potential area but also logistics market. Logistics service in the direction of 3PL is already present and has great potentials for development in Vietnam. Therefore, if only providing simple and pure logistics services without integrating them into the process, service chain and service providers can hardly satisfy customers in terms of cost reduction, as well as quick responsiveness (Vietnam Logistics Report, 2019).

In Vietnam, it can be seen that one of the reasons why logistics services of many enterprises are unprofessional is because of poor IT application level. Applying technology in the era of industrial revolution 4.0, when the volume of goods transported is high, the demand for time, as well as ensuring the safety and quality of goods are still not acquired by many businesses.

About the connection between service providers: In the current trend of outsourcing logistics, each business needs to focus on its strengths and outsource services that are not strengths, therefore, the links between businesses providing this type of service is necessary. Even logisitics businesses do not have a proper logisitics association, but there are five associations related to this field: Vietnam Logistics Business Association (VLA), Shipowners Association Vietnam (VSA); Vietnam Automobile Transport Association (VATA), Vietnam Association of Shipping Agents and Brokers (VISABA); Vietnam Seaports Association (VPA) and Vietnam Shippers Association (VNSC). These associations all gather firms that supply or involve logistics but have not established industry linkages, lack of cooperation to complement each other's advantages. Since each association has different characteristics, access to sectoral authorities is also at different angles. Therefore, it is difficult to create uniform and synchronized policies for the logistics industry, especially in human resources training, information technology, investment in logistics infrastructure. Currently, Vietnam has not had regional and world-class logistics brands to be "locomotives" for this service industry to develop in the right direction.

\section{Actual situation of providing freight services}

Freight services are a common logistics service provided in Vietnam. The main types of transport services are: ocean transport services, road transport services, railway transport services, inland waterway transport services (river ways) and air transport services. The volume of transport through these modes of transport in Vietnam during the past time is shown in Table 4:

-Road transport services: output in 2015 reached 51,514.9 million tons of goods and in 2018 reached 70,566.7 million tons of goods. The average growth rate in the period of 2015 and 2018 will reach over 110 percent. The volume of goods transported by road accounted for an average of 24.2 percent of the total volume transported by all modes during the period of 2015 to 2018 (General Statistics Office of Vietnam).

- Ocean transport services: the output in 2015 reached 131,835.7 million tons of goods and in 2018 reached $148,024.6$ million tons of goods. The average growth rate during the period of 2015 and 2018 reached 103.3 percent. The volume of goods transported by sea accounted for an average proportion of 55.4 percent of the total volume of goods transported by all modes during 2015 and 2018 (General Statistics Office of Vietnam).

- Rail transport service: the output in 2015 will reach 4,035.5 million tons of goods, in 2018, there will be 4,025.4 million tons of goods. The average growth rate during the period of 2015 and 2018 reached 99.3 percent. The volume of goods transported by rail accounted for an average of 1.5 percent of the total volume of goods transported by all modes during 2015 and 2018 (General Statistics Office of Vietnam).

- River transport services: output in 2015 reached 42,064.8 million tons of goods, in 2018 reached 51,528.8 million tons of goods. The average growth in the period of 2015 and 2018 reached 106.5 percent. The volume of 
goods transported by river accounted for an average proportion of nearly 18.6 percent of the total volume of goods transported by all modes during 2015 and 2018 (General Statistics Office of Vietnam).

- Air transport services: output in 2015 reached 599.5 million tons of goods, in 2018 reached 1,068.9 million tons of goods. The average growth in the period 2015 and 2018 reached 119.7 percent. The volume of goods transported by air accounted for an average proportion of nearly 0.3 percent of the total volume of goods transported by all modes from 2015 to 2018 (Vietnam General Statistics Office).

Table 4. Volume of goods transported by Vietnamese modes of transport (2015-2018)

\begin{tabular}{lcccccc}
\hline & Total & Railway & Roadway & River way & Seaway & Air route \\
\hline Volume of rotating goods (Million tons.km) & & & & & & \\
2015 & $230,050.4$ & $4,035.5$ & $51,514.9$ & $42,064.8$ & $131,835.7$ & 599.5 \\
2016 & $241,376.9$ & $3,198.2$ & $57,377.3$ & $44,925.2$ & $135,171.2$ & 705.0 \\
2017 & $255,932.9$ & $3,616.7$ & $63,459.3$ & $47,800.4$ & $140,307.7$ & 748.8 \\
Preliminary 2018 & $275,214.4$ & $4,025.4$ & $70,566.7$ & $51,528.8$ & $148,024.6$ & $1,068.9$ \\
Development index (Previous year = 100) -\% & & & & & & \\
2015 & 103.1 & 93.6 & 106.9 & 104.9 & 101.4 & 112.2 \\
2016 & 104.9 & 79.3 & 111.4 & 106.8 & 102.5 & 117.6 \\
2017 & 106.0 & 113.1 & 110.6 & 106.4 & 103.8 & 106.2 \\
Preliminary 2018 & 107.5 & 111.3 & 111.2 & 107.8 & 105.5 & 142.7 \\
\hline
\end{tabular}

Source: GSO

\section{Situation of logistics infrastructures in Vietnam}

Port network: Vietnam is considered as a country with a favorable position for the development of a seaport network with a coastline of $3,260 \mathrm{~km}$, stretching over 15 parallel lines, running along the whole length of the country. The coastal areas of Vietnam have many large rivers pouring into the sea, creating favorable conditions for the construction of seaports. The 2019 statistics of Vietnam Maritime Administration shows that the whole country has 281 ports with a total capacity of over 550 million tons / year. Port system is invested synchronously in infrastructure: wharves, buoys, loading and unloading equipments, basic development complete, fully functional, large scale and widely distributed by region. domain. Most ports make full use of natural conditions, meet the requirements of transporting goods by sea, actively serving the socio-economic development process of coastal areas and the whole country, create motivations to attract and promote related industries and others to develop together. Most of the regional major ports: Hai Phong, Da Nang, Ba Ria - Vung Tau, Ho Chi Minh City have been upgraded to receive ships of up to 30,000 DWT. Typically, Cai Mep - Thi Vai port receives ships of up to 18,300 TEU (194,000 DWT), which is operated weekly, directly connecting Vietnamese imports and exports to the Northern-European market. In the Central region, the seaport is also on a "prosperous" momentum, especially in Da Nang port. Before 2014, Da Nang port had a limited wharf length, container ships had to queue for 6-8 hours. After equitization, the port focused on upgrading the wharf infrastructure and developing container services. The total investment for the period of 2014 - 2018 is more than VND 1,900 billion, which is four times higher than the period of the previous 5 years (2009 - 2013). The port continued to put into use 2 new wharves in the project of expanding Tien Sa port phase 2, with a total investment of nearly VND 900 billion. Output of goods through the port in the past 5 years has increased on average 10\% / year. The receiving capacity has been raised from 1,800 TEU to 3,500 TEU, the situation of waiting ships is almost not available (Vietnam National Shipping Lines, 2019).

Currently, connecting major seaports in the world uses transport modes such as railways and highways. The system of Vietnamese seaport has only Hai Phong port connected to the railway but the operation efficiency is very low (Cai Lan port has been invested but has not been able to operate due to lack of synchronous gauge) with no highways, particularly for freight transport. Waterway transportation is restricted by the province having no bridges crossing the river. Therefore, the efficiency in transporting goods to the seaport has not been 
optimized in terms of time and transportation costs. Therefore, it is necessary to invest in connecting seaports with multimodal transport in order for the port system to develop sustainably and logistics costs to be pulled down. Currently, many coastal provinces are focusing on calling and attracting projects on seaports, logistics centers such as Thanh Hoa, Ha Tinh, Da Nang, etc. Vung Ang Economic Zone is one of nine coastal economic zones, selected by the Government to develop the center of steel, thermal power and deep-sea ports of the Central region. Currently, Vung Ang Economic Zone has attracted 137 investment projects, including 80 domestic investment projects and 57 FDI projects. These projects focus on the fields of industry, wharves, thermal power, renewable energy, post-steel development. Many large foreign enterprises are also exploring investment surveys in Vung Ang such as: Joint venture between Lee \& Man Group (Hong Kong), Hokuetsu (Japan), Xiamen Port Group (China). These corporations have proposed to research and survey to build a large-scale port and logistics center. If these investment projects are implemented, it will connect Vung Ang seaport to international seaports, as well as domestic road transport systems via Laos and Thailand (Vietnam Logistics Report, 2019).

Vietnamese maritime fleet: According to a report of the Vietnam Maritime Administration, as of June 2019, Vietnam's fleet has 1,568 ships (of which 1,106 transport ships) with a total tonnage of about 7.8 million tons, ranking the fourth in ASEAN (after Singapore, Indonesia, Malaysia) and the 30th in the world. The average age of Vietnamese fleet is 15.6 years old, 5.2 years younger than the world (20.8 years old). The structure of the fleet has also grown towards specialization, especially, which has grown well from 19 ships in 2013 to 39 ships in 2019 (Vietnam logistics report, 2019).

Road network: The total length of the roads is about $559,162 \mathrm{~km}$, including 154 national highways with a total length of $24,866 \mathrm{~km}$, provincial roads of $28,143 \mathrm{~km}$, district roads of $57,033 \mathrm{~km}$, in addition to urban roads of over $27,688 \mathrm{~km}$, the rest are roads with $159,102 \mathrm{~km}$ commune. Quality of roads has been newly built, repaired and maintained regularly. In general, the entire system of paving rate is 51,258 km (approximately 17\%) (Vietnam Logistics Report, 2019).

Table 5. Vietnam's road network

\begin{tabular}{lcc}
\hline \multicolumn{1}{c}{ Type of ways } & Length $(\mathbf{k m})$ & Proportion \% \\
\hline Highway & 1,010 & 0.18 \\
Route & 24,866 & 4.45 \\
Provincial Highway & 28.143 & 5.03 \\
District road & 57,033 & 10.20 \\
Commune road & 159.102 & 28.45 \\
Urban road & 27,688 & 4.95 \\
Other rural roads & 253.275 & 45.30 \\
Specialized road & 8.045 & 1.44 \\
Total & 559.162 & 100 \\
\hline
\end{tabular}

Source: Vietnam logistics report, 2019

National highways are the main arteries of the entire network. The national highways create the North-South corridor running along the country, in addition, there are East-West routes. In the North, the national highways form a fan shape, while in the South, the national highways form a chessboard. In general, the national highways have quite good coverage. However, most of the roads are very narrow and the road surface quality is very poor.

Regarding the hierarchy of roads by function, from Table 5, it can be seen that the proportion of national highways (main roads) compared to provincial roads (secondary roads) is not much different, while in developed countries, the length of the secondary road network should be at least twice as long as the main road network. This makes the local traffic on the national highways too big, cause traffic congestion, increase the number of traffic accidents, and rapidly degrade road quality due to the rapid increase of traffic.

Waterway network: Across Vietnam, there are about 2360 rivers and canals with a total length of about 220,000 $\mathrm{km}$. In which, only about 19\% (about 42,000 km) is capable of transport operation and 7\% (15,440 km) is being managed and exploited. The river system in Vietnam is divided into three groups according to geographical region. In the North, the river system is formed by four main rivers: Red River, Thai Binh River, Luoc River and Duong River. The minimum width of the river bed ranges from 30 to 36 metres, the minimum depth is from 1.5 to 3.6 metres. Water transport routes in the Northern region are about 2,750 km long, including 65 state-run routes (Vietnam Inland Waterway Administration). 
Meanwhile, inland waterway transport in the Mekong Delta depends on two main rivers: the Mekong River and the Dong Nai River. Water transport on these rivers is more convenient than those in the North, with a minimum width of 30 to 100 metres and a minimum depth of 2.5 to 4 metres, total length of up to about $3,020 \mathrm{~km}$, including 101 routes are managed by the government. In the Central region, rivers flow from west to east and do not form a network. The total length of the rivers and canals is about $800 \mathrm{~km}$, but due to the terrain with many rapids and limited depths, it is not favorable for transportation. The whole central region has only 21 transport routes, most of which are about $20 \mathrm{~km}$ short near the estuaries (Vietnam Inland Waterway Administration).

Inland ports and wharves:

Inland waterway port: Up to now, Vietnam has 285 ports, of which 210 cargo ports, 12 passenger ports, 63 ports

specialized use. Out of 285 inland waterway ports, eighteen ports announced by the Ministry of Transport are allowed to receive foreign waterway vessels (fifteen cargo ports, two passenger ports, one specialized port). On the national waterway, there are 225 ports ( 161 cargo ports, five passenger ports, 59 specialized ports). On the local inland waterway, there are 60 ports ( 49 cargo ports, seven passenger ports, four specialized ports).

Inland wharves: Vietnam currently has 8,217 inland wharves, of which 6769 are licensed and 1,448 are not allowed, accounting for 17\%. In particular, there are 3,191 licensed berths and 1,199 unlicensed stations on the national route of UMW and on the local IWT route: 3,578 licensed berths, 249 unapproved terminals (Vietnam Logistics Report, 2019).

Although the inland port system has been rapidly developing, there are mainly small-scale ports serving the business and production activities of that enterprise. As the volume of cargo throughput is low, it only meets part of the demand. As the demand for cargo handling by inland waterways increased, the number of small-sized ports increased. Ports of this type are of very low investment quality, often small in scale, with limited traffic connectivity, unprofessional operators, loading and unloading equipment at ports are generally outdated, manual stacking is large, lacking specialized loading and unloading equipment (grain, food, container, packages).

Railway network: Vietnam currently has $2524 \mathrm{~km}$ of railway, of which $2124 \mathrm{~km}$ is a railway with aperture of $1000 \mathrm{~mm}$, the rest is with aperture of $1435 \mathrm{~mm}$. The main railway line is the Hanoi-Ho Chi Minh City route (also called Thong Nhat route), which is $1726 \mathrm{~km}$ long, while the other lines are small ones, with distances of only a few dozen kilometres, such as the Hanoi-Hai Phong route with $102 \mathrm{~km}$, Hanoi - Dong Dang: $162 \mathrm{~km}$ (see table 6). Vietnam railway system is connected to China through two directions: with Yunnan province (China) through Lao Cai province and with Guangxi province (China) through Lang Son. Technically, Vietnam railway uses wooden and iron sleepers through two concrete blocks, $43 \mathrm{~kg} / \mathrm{m} 3$ rails are used on almost the entire network and use the hard link between rails and sleepers. Recently, some types of elastic linkage between rails and sleepers have been used in some sections. Railways are mainly used for passenger transportation, cargo transport capacity is still limited (Vietnam Railway Corporation, 2019).

In general, railway infrastructure is considered backward and weak compared to other countries in the region; Transport capacity is generally low due to small scale and not modernized. Many sections of the road go through complex geological terrain, mountainous areas become small radius of curves, low passage speed, many sections along rivers and streams greatly affect their capacity and safety. download. On the whole route there are too many categories, the percentage of sleepers accounts for 30-35\%. Accessories are mostly hard, recently elastic accessories have increased but not much. Most recorded 20-30 years ago, the number of records replaced is negligible compared to the total number of records. Status worn, chipped recorder blades, vertical wear, horizontal, center recording, ray wings recorded more. Accessories loose links, loss, rust. The railway bridges have been used for quite a long time, most of them are restored to run the train. The steel girder beams belong to many different categories from many countries such as Belgium, France, USA, Germany, the former Soviet Union, China with different technical standards, making it difficult for maintenance and repair. The railway tunnels are in the old condition, many leaky water tunnels, narrow gauge, poor drainage (Vietnam Railway Corporation, 2019). 
Table 6. Vietnam's railway system

\begin{tabular}{lcc}
\hline \multicolumn{1}{c}{ Route } & Length $(\mathbf{k m})$ & Aperture $(\mathbf{m m})$ \\
\hline Hanoi - HCMC & 1,726 & 1,000 \\
Hanoi - Hai Phong & 102 & 1,000 \\
Hanoi - Lao Cai & 296 & 1,000 \\
Hanoi - Dong Dang & 162 & $1,435 \& 1,000$ \\
Hanoi - Quan Trieu & 75 & $1,435 \& 1,000$ \\
Kep - Uong Bi - Ha Long & 106 & 1,435 \\
Kep - Luu Xa & 57 & 1,435 \\
\hline
\end{tabular}

Source: Vietnam Railway Corporation

The system of warehouses, wharves on railway lines, especially Thong Nhat route, is small in scale and unable to meet the requirements of goods transportation. At the stations, the goods are stored in the station's warehouses, on the carriages and placed in the natural yards. The only rail transport service provider, Vietnam Railway Corporation, currently has more than 300 locomotives and 5,000 carriages, of which more than half of them are old carriages and have been used for several decades. The remaining ones are not new. Most wagons are ordinary freight wagons and very few wagons are specialized to carry special goods. The two stations with the largest cargo-related service activities are Hai Phong and Song Than stations. Hai Phong railway station has a cargo handling capacity of about 3,000 tons per day, unloading capacity of about 2,500 tons per day, an enclosed warehouse with an area of $500 \mathrm{~m} 2$. Song Than Station has an area of over $200,000 \mathrm{~m} 2$ of warehouse (Vietnam Railway Corporation, 2019). Investment in railway development is still facing difficulties because of high synchronization requirements from infrastructure, locomotives, carriages, signal information systems, train operation, repair facilities, equipments repair, maintenance, etc. Therefore, the railway investment rate is large, the commercial advantage is low compared to other types of investment, the payback period is long, the feasibility of calling for early socialization investment is not high, not appealing to investors. Investment in railways is usually 3 to 4 times higher than on roads. For example, $1 \mathrm{~km}$ of 1,435 mm gauge is often 4 times higher than that of grade 3, high-speed rail is 4 times higher than highways (Railway Corporation Vietnam, 2019). Over the years, the State has encouraged and called for investment in railways, however, investors are not interested. Therefore, the investment in railway field development needs the State's steadiness in infrastructure investment, some items such as the station may call for private exploitation and localization of some urban railway lines. Municipalities may call for private investment by nearby urban development or assistance. The state can also assign private infrastructure to be exploited by franchising.

Airway network: According to the Civil Aviation Administration of Vietnam, there are currently 39 large and small airports, including 22 civil airports. Among them, the only 10 airports are Tan Son Nhat (Ho Chi Minh City), Noi Bai (Hanoi), Da Nang, Phu Bai (Hue) and Cam Ranh (Khanh Hoa), Phu Quoc (Kien Giang). ), Vinh (Nghe An), Van Don (Quang Ninh), Cat bi (Hai Phong), Can Tho that have international flight schedules. For domestic routes, the currently operating airlines are Vietnam Airlines, Jetstar Pacific Airlines (formerly known as Pacific Airlines with $86 \%$ of Vietnam Airlines), BamBoo Airways is an airline. Vietnam belongs to FLC Group, Vietjet Air is established from three main shareholders, namely T\&C Group, Sovico Holdings and Ho Chi Minh City Housing Development Commercial Bank (Vietnam Civil Aviation Department, 2019). Many airports in Vietnam are overloaded and operating at full capacity. The capacity of the aviation structure system is currently in shortage of infrastructure, which hinders economy and tourism, many airports are overloaded when exceeding the designed capacity. Tan Son Nhat airport overloaded for many years, with a capacity of 28 million passengers, is currently welcome to 38.31 million (2018). Similarly, other six airports are under lighter load, including: Noi Bai International Airport with a designed capacity of 21 million passengers, in 2018 this airport welcomed 25.85 million passengers; Da Nang international airport with a capacity of 10 million passengers but has welcomed 13.23 million passengers; Cam Ranh Airport with a capacity of 5.1 million passengers, receiving 8.25 million passengers; Cat Bi International Airport with a capacity of 2 million passengers, welcoming 2.31 million guests. The two smaller airports, Phu Bai Airport, has a capacity of 1.5 million passengers, but in 2018, the airport also had 1.83 million passengers, and Pleiku Airport with a capacity of 600,000 passengers also welcomed 720,000 guests. The investment in expanding and upgrading the airport infrastructure is essential, but the problem is the investment approval, capital allocation and investor decisions still face many difficulties (Vietnam Logistics Report, 2019 ).

\section{Legal system, logistics development policy in Vietnam}

Nowadays, in Vietnam, there is no unified state management agency in the field of logistics and logistics service 
business, but there exists many different agencies managing different types of logistics services. Mechanism of decentralized vertical management such as the Ministry of Transport - Department of Maritime Administration, marine transport management, Civil Aviation Administration managing air transport, General Department of Roads manages road transport, Department of Roads inland water transport management inland; The Ministry of Industry and Trade managing logistics, creating specialization in the management of logistics services as separate business areas.

On February 14, 2017, the Prime Minister of Vietnam signed the issuance of Decision 200 approving the Action Plan to improve competitiveness and develop Vietnam logistics services to the year 2025. This is the first time Vietnam has a legal document affirming its determination to develop the logistics service sector, and at the same time to devise practical, medium-term solutions to support logistics development in Vietnam. There are Decree No. 163/2017 dated on December 30, 2017 providing for logistics services business and Directive No. 21 / CT-TTg dated July 18, 2018 on promoting the implementation of solutions to reduce logistics fees, make efficient connection of transport infrastructures. The action plan, regulations of logistics service from the drastic Directive of the Government and the Prime Minister are highly disruptive. This creates a legal corridor and open a healthy business environment for Vietnamese logistics operations to increasingly develop sustainably.

On June 7, 2019, the Prime Minister signed Decision No. 703 approving the scheme "Building a competitive transport market in the direction of developing multimodal transport, connecting between different transportation modes, paying attention to the importance of the application of information technology to minimize transportation costs to facilitate the circulation and distribution of goods and services of enterprises". Accordingly, developing the freight transport market in the direction of promoting the advantages of each mode of transport, in association with the task of transport restructuring to reduce the market share of road transport, increase the market share of rail transport, inland waterways, seaways, and strengthening connectivity between modes of transport to develop multimodal transport and high-quality logistics services.

Decision No. 105 on January 22, 2019 was approved by the Prime Minister, the scheme on "Enhancing aviation connectivity with tourism markets". The scheme aims to open new air routes, increase the frequency on existing routes of Vietnamese and foreign airlines between Vietnam and key tourist markets in the world. Also, this includes opening new domestic routes to connect key tourist areas in the Northeast, the Central region, the Central Coast, Central Highlands, Central Highlands, Mekong Delta and Phu Quoc, contributing to the development of tourism into a spearhead economic sector. By 2020, they continue to deploy the plan to open international routes under the Project "Orientation of developing direct air routes between Vietnam and key countries in order to promote development investment and enhance international integration", which was approved by the Prime Minister in Decision No. 2119 on December 28, 2017.

\subsection{Status Assessment of Vietnamese Logistics Development}

\section{Results}

From the above analysis, it shows that the development of the logistics system has the following basic advantages:

- The market has a high growth rate thanks to the growth of import-export activities and distribution services, the number of businesses established and operated in the industry is quite large, including many economic sectors.

- Vietnam has a legal system that regulates logistics services to increasingly improve.

- Vietnamese logistics performance and efficiency are increasing and 2018 is considered a successful year for its logistics. Vietnam's ranking in the world jumped 25 levels, from 64 (2016) to 39; LPI score increased sharply from 2.98 to 3.27 points. All six criteria for LPI evaluation in 2018 increased dramatically, in which the highest increase was service quality capacity (ranked $33^{\text {rd }}$, up 29 places in rank and 0.55 points in points) and ability to track and trace goods (ranked 34th, increased 41 places in rank and 0.61 points in score.

The criteria for good evaluation are Customs clearance (ranked $41^{\text {st }}$, up 23 ranks), Logistics infrastructure (ranked $47^{\text {th }}$, up 23 ranks) Delivery Time criteria (ranked $40^{\text {th }}$, up 16 grades) and the criteria for International Delivery (ranked $49^{\text {th }}$, up 1 rank) also improved. This reflects the current situation of improving the capacity of enterprises through the application of information technology in the field of logistics. At the same time, this is the result of the Government's reforming efforts in creating a business environment and improving the competitiveness of businesses in the economy in general and logistics services in particular, as well as efforts to improve the intrinsic business itself (Guidance document on Logistics performance index) (LPI) - Ministry of Industry and Trade of Vietnam). 
Table 7. Vietnam's LPI rating over the years

\begin{tabular}{ccccccccc}
\hline Year & Ranking & Marks & $\begin{array}{c}\text { Customs } \\
\text { clearance }\end{array}$ & Infrastructure & Delivery & Capacity & Access & Time \\
\hline 2007 & 53 & 2.89 & 2.89 & 2.50 & 3.00 & 2.80 & 2.90 & 3.22 \\
2010 & 53 & 2.96 & 2.68 & 2.56 & 3.04 & 2.89 & 3.10 & 3.44 \\
2012 & 53 & 3.00 & 2.65 & 2.68 & 3.14 & 2.68 & 3.16 & 3.64 \\
2014 & 48 & 3.15 & 2.81 & 3.11 & 3.22 & 3.09 & 3.19 & 3.49 \\
2016 & 64 & 2.98 & 2.75 & 2.70 & 3.12 & 2.88 & 2.84 & 3.50 \\
2018 & 39 & 3.27 & 2.95 & 3.01 & 3.16 & 3.40 & 3.45 & 3.67 \\
\hline
\end{tabular}

Source: World Bank

- Logistics infrastructure has initially met the development of Logistics industry. Training and application of supporting technologies for logistics services. The number of schools, institutes and facilities participating in logistics training is increasing, the training program is upgraded towards intensive, professional, practical and lecturers have increased in number and upgraded to high level. As of October 2019, of the 286 universities across the country, 28 have enrolled and trained in majors or logistics majors. Many technological solutions applied in warehouse management, vehicle management, cargo management help logistics services to be implemented better and faster (Vietnam Logistics Report, 2019).

\section{Limitations}

- The market of logistics services has not developed well with its potentials and has not become a driving force or a key factor contributing to increase national competitiveness and for businesses. Enterprises providing logistics services in Vietnam are small-scale with limited financial resources. The main types of services provided are basic services such as transportation services, warehousing, shipping, etc., which have not provided high value-added services.

- The weakness of logistics infrastructures, especially transportation infrastructure, which increases logistics costs, increases product transit time and reduces customer trust in services of supply industry.

- The organization and management of logistics activities are still overlapping and inappropriate. In the field of logistics, there is currently no specialized state management agency, which has the function of managing these types of transactions. There is no committee that is responsible for managing the development of Logistics as a conductor as in Singapore, Malaysia and Thailand.

- With the characteristics of the newly developed logistics service market in recent years, Vietnamese logistics workforce has its strong point of being young, dynamic, adventurous and willing to take challenges and risks. However, the problem that Vietnam is facing is a lack of quantity in human resources, weak qualifications and professionalism. Besides, the preparation of knowledge, skills, attitudes and psychological status of Vietnamese logistics workers to be ready to receive the wave of labor movement between ASEAN countries is not high. Labor discipline issues, the sense of compliance with the law as well as low labor intensity are also the limitations that need to be overcome in the upcoming years for Vietnamese logistics manpower (Vietnam Logistics Report, 2019).

\section{Causes}

- Because of unexploited economic advantages and potentials of each city, infrastructure for logistics activities as well as the connection between commercial infrastructure, transport infrastructure and information technology infrastructure are still not high. These are the reasons hindering the sustainable development of domestic logistics enterprises and pushing up logistics costs in Vietnam.

- A number of regulations are overlapping, there are inappropriate administrative procedures and specialized inspection. A number of policies have not been promptly revised to suit the specific characteristics of logistics activities in practice.

- According to the Ministry of Industry and Trade, service costs are still high due to many reasons such as limitations on the size of enterprises and capital, the abilities to apply information technology as well as the human resource level, which do not meet operational requirements, restrictions on logistics infrastructure and road transport costs, port surcharges imposed by foreign ship owners ... 
- The statistical work, assessing the situation of logistics development still face many difficulties and inadequacies. Statistical data is an important basis for conducting accurate researches and assessments of the situation and making recommendations on mechanisms and policies. However, at present, the statistics and the assessment of the situation of logistics development still face many difficulties since there is no uniformity and consistency.

- Ministry of Industry and Trade pointed out, the contingent of state management officials about logistics is still limited in terms of manpower and qualifications. Many cadres have not been trained in the right fields, working on a part-time basis, therefore, they have many difficulties in management. State payrolls allocated for logistics management are still limited, shortages lead to frequent overcrowding, affecting the quality of assigned work.

\section{Recommendations for Vietnamese Logistics Development in the Context of International Economic Integration}

\subsection{Develop the Supply of Goods of the Economy}

One of the functions of the national logistics system is to ensure the supply of goods for the economy. To develop the supply of goods, the following basic measures must be implemented:

- Developing channels of goods distribution of the economy. These are essential for the routes in the logistics system. It is necessary to organize links between enterprises in the supply chain of goods in the economy in order to establish a distribution and consumption system of domestic products on the market; taking advantage of the international distribution network to bring Vietnamese goods to foreign countries in order to expand production and develop exportations; as well as distributing imported products from foreign countries to customers of the national economy.

- The Government needs to have a master plan in order to calculate and select locations to develop national logistics centers, especially in key economic regions of the country. When planning, it is necessary to take into account the factors to ensure the sustainable development of a logistics center: technical infrastructures, human resources and policy mechanisms. In particular, hardware is the technical infrastructure, the port system is the nucleus of logistics development. In addition to the system of modern equipment, human resources need a management team and high-quality human resources.

- Implementing measures to ensure smooth and fast movement of goods in the entire system such as creating favorable conditions for multimodal transport; calculating and organizing the collection of charges related to transportation and loading and unloading in a reasonable manner; implementing measures to minimize traffic accidents and traffic jams; simplifying procedures related to shipping, transportation, customs clearance and reducing harassment on freight routes throughout the economy.

\subsection{Developing Vietnamese Logistics Service System}

Developing logistics service system should focus on these following solutions:

- Developing various types of logistics services. Service-providing businesses need to develop diversified services with high added value such as: Air freight shipping (from door to door), maritime shipping (from door to door), products management/transporter, consolidating at warehouses, orders management; managing and tracking supplier's commitments, value-added warehouse services, consolidation from many countries to a transshipment port, quality control services, production process control services on time, Managing data and providing end-to-end data for customers, barcodes scanning and printing services, document delivery service, services suspended containers (for garments), services of distribution of goods, services of monitoring and checking goods via Internet, Customs brokerage services, entrusted import and export, customs declaration, etc.

- It is necessary to strengthen joint-venture activities with foreign partners when providing services. Currently, due to the limited size and capacity, Vietnamese businesses mainly provide logistics services individually, they do not provide a complete logistics process which are mainly agents for foreign logistics corporations. The participation of Vietnamese businesses in joint ventures and partnerships with foreign partners have brought many benefits and allow them to learn management experience and methods of managing the logistics system; receiving financial support, technology, facilities, materials and technical facilities and skills from foreign partners; as well as the opportunity to expand business relationships and access to large markets of foreign partners.

- It is necessary to strengthen the linkage and cooperation between enterprises providing logistics services and establishing logistics associations. Currently in the field of logistics, there are many associations such as Logistics Service Business Association, Vietnam Supply Chain Association (VSC), Vietnam Seaport Association 
(VSA), Vietnam Shipowners Association, Association Vietnam Association of Shipping Agents and Agents, but these associations focus on gathering businesses, experts in each field related to logistics services, rather than a full group of enterprises operating in the field of logistics service providers. Therefore, it is possible to unite these associations into a unified organization, with a role of representing interests for logistics businesses. The establishment of the Association has an active role in supporting and advising firms, which is a bridge for them to connect with each other in business activities. Logistics associations also act as a bridge to state management agencies, foreign relations with international partners, where researches and development activities are carried out, and also the promulgation and management of standards, documents, forms, statistics, evaluation criteria of the industry.

\subsection{Developing Consumers Market of Logistics Services}

The development of a consumer market of logistics needs to target three main groups of customers: the group of domestic production and business enterprises, the group of domestic import-export enterprises and the group of enterprises with foreign investments. Multinational logistics service providers operate in a variety of activities, especially in the field of 3PL package services with modern technology. They have won contracts to provide logistics services for most foreign-invested enterprises in Vietnam. Domestic enterprises are mostly small businesses, acting as providers of satellite services to foreign businesses, only take a small part in the entire logistics service chain such as: customs notice, rental of means of transport, warehousing (forwarding). However, the World Bank's evaluation shows that Vietnam has an average LPI index of 39, ranking first among 10 middle-income countries with low income (World Bank). This shows that the logistics industry still holds great potentials with high growth rates. Import-export turnover and the high growth of the retail industry will also be factors to promote the strong development of this service industry. Thus, the "segment" of the key consumer market that logistics service providers need to target is domestic production and business enterprises and domestic import-export enterprises.

\subsection{Developing Logistics Infrastructure}

- To quickly develop the maritime industry, there are a few things that need to be done: building deep-water ports and regional ports; making good use of river ways in both the Mekong River Delta and the Red River Delta. To develop coastal transport routes together with capacity building of port systems, developing appropriate fleets of ships which includes sea fleets to transport North-Central-South goods from centers of the Red River delta such as Hanoi to the Mekong Delta and vice versa from the two plains to the central provinces, is important.

- Regarding roads, it is necessary to prevent deterioration step by step to upgrade important roads. Gradually upgrading the major national highways, forming a relatively modern synchronous traffic network in all three key economic regions.

- Upgrading critical railway sections and Thong Nhat railway bridge system.

- Expanding and modernizing international exchange hubs (seaports, international airports). Developing the new routes linking the trans-Asia axis and with neighboring countries.

- Strengthening and diversifying investment capital sources for developing transport infrastructures to develop logistics infrastructure. It is necessary to encourage and create conditions for all economic sectors, including foreign-invested enterprises, to participate in infrastructure development, concentrating resources to prioritize renovation, upgrading and constructing new transportation system.

\subsection{Completing the System of Laws and Policies on Logistics Development in Vietnam}

The legal and institutional factors are very important conditions for the development of logistics service businesses, as well as the framework for effective state management in this area. In order to perfect the system of laws, institutions and policies on national logistics development, it is necessary to focus on the following solutions:

- The Government needs to revise the system of legal documents regulating logistics service business to have a comprehensive and comprehensive system of legal documents as a framework for state management of the type of services.

- State management practices also require the establishment of a specialized logistics management agency in Vietnam. It is necessary to have a functional body to sequence all logistics activities as well as factors related to the supply process of these elements to effectively manage the state. This agency can be named after the National Logistics Committee, performing tasks related to state management and policy making in this field, including: Research and propose regulatory regulations. logistics activities in the economy; Attract and call for 
investment in the development of logistics infrastructure, coordinate with functional agencies to formulate policies on investment and development of logistics infrastructure; Consulting, supporting the establishment of logistics enterprises; Researching and applying science and technology in logistics; Planning policies to develop the logistics system of the economy; Cooperating with international organizations, international corporations on logistics, etc.

\section{Conclusion}

In the context of globalization, Vietnamese authorities need to develop and improve the legal framework and policies for sustainable development and logistics efficiency. At the same time to maximize the advantages of the geographical position and natural conditions of the country, to socialize the investment in logistics infrastructure, to mobilize to the utmost all resources, Vietnam's logistics industry will definitely develop and strongly grow.

\section{References}

Andrii, G., Constantin, D., \& Nataliia, D. (2017). The Role of Consumers in Logistics Systems. Transportation Research Procedia, 27, 1187-1194. Retrieved from https://doi.org/10.1016/j.trpro.2017.12.010

Anh, H. (2018). 90\% doanh nghiệp logistics Việt Nam có vốn đăng ký duới 10 tỷ đồng [90\% of logistics enterprises in Vietnam have registered capital of less than 10 billion dong]. Retrieved from https://haiquanonline.com.vn/90-doanh-nghiep-logistics-viet-nam-co-von-dang-ky-duoi-10-ty-dong-61685. html

Communist Party of Vietnam. (2011). Documents of the 11th National Party Congress. Ha noi, True National Political Publishing House (Vn.).

Dao, D. (2011). Logistics: Theoretical and practical issues in Vietnam. Ha noi National University Publishing House ( $\mathrm{Vn}$.).

Dao, D., Loi, T., Son N., \& Hang D. (2019). Logistics service in Vietnam in the process of international integration. Ha noi, Dan Tri Publishing House (Vn.).

Dao, D., \& Chi, N. (2019). Phát triển logistics xanh cho tăng truởng bền vũng [Developing green logistics for sustainable growth]. Retrieved from http://vinalines.com.vn/vi/phat-trien-logistics-xanh-cho-tang-truong-ben-vung/

Decision No. 2190 / QD-TTg of the Prime Minister on the approval of the Planning on development of Vietnam's seaport system to 2020, with orientations to 2030 (2009) (Vn.).

Decision No. 318 / QD-TTg of the Prime Minister on the approval of the Transport Service Development Strategy to 2020 with orientation to 2030 (2014) (Vn.).

Decision No. 200 / QD-TTg of the Prime Minister on approving the Action Plan to improve competitiveness and develop Vietnam's logistics services to 2025 (2017) (Vn.).

Decision No. 2119 / QD-TTg of the Prime Minister Approving the Scheme on direct development of direct flights between Vietnam and key countries and regions to promote development investment, enhance exchanges and associations. international import (2017) (Vn.).

Decision No. 105 / QD-TTg. (2019, January 22) of the Prime Minister approving the Scheme 'Strengthening air connectivity to tourist source markets" (2019) (Vn.).

Decision No. 703 / QD-TTg of the Prime Minister approved the Project "Building a competitive transport market in the direction of developing multimodal transport, connecting between different forms of transport, focusing on technology application. information to minimize transportation costs to facilitate the circulation and distribution of goods and services of the business". (2019) (Vn.).

Decree No. 163/2017 / ND-CP of the Government regulates logistics service business (2017) (Vn.).

Directive No. 21 / CT-TTg of the Prime Minister on promoting the implementation of solutions to reduce logistics costs, effectively connect the transport infrastructure (2018) (Vn.).

Douglas, M. L., Martha C. C., \& Janus D. P. (1998). Supply Chain Management: Implementation Issues and Research Opportunities. The International Journal of Logistics Management, 9(2), 1-20. https://doi.org/10.1108/09574099810805807

Duc, P. (2020). 5 bất cập đang "cản chân” ngành logistics Việt Nam $[5$ shortcomings are "hindering" Vietnam's logistics industry]. Retrieved from https://haiquanonline.com.vn/5-bat-cap-dang-can-chan-nganh-logistics-viet-nam-122394.html 
EU - Vietnam Multilateral Trade Assistance Project MUTRAP III. (2009). Report on overall strategy for service sector development up to 2020 and vision to 2050. Retrieved from http://www.trungtamwto.vn/upload/files/wto/8-tai-lieu-tham-khao/Chi\%E1\%BA\%BFn\%201\%C6\%B0\%E1 $\%$ BB $\%$ A3c\%20t\%E1\%BB\%95ng\%20th\%E1\%BB\%83\%20ph\%C3\%A1t\%20tri\%E1\%BB\%83n\%20ng\%C 3\%A0nh\%20d\%E1\%BB\%8Bch\%20v\%E1\%BB\%A5\%20t\%E1\%BB\%9Bi\%20n\%C4\%83m\%202020\%20v $\% \mathrm{C} 3 \% \mathrm{~A} 0 \% 20 \mathrm{t} \% \mathrm{E} 1 \% \mathrm{BA} \% \mathrm{~A} 7 \mathrm{~m} \% 20 \mathrm{nh} \% \mathrm{C} 3 \% \mathrm{ACn} \% 20 \mathrm{t} \% \mathrm{E} 1 \% \mathrm{BB} \% 9 \mathrm{Bi} \% 20 \mathrm{n} \% \mathrm{C} 4 \% 83 \mathrm{~m} \% 202025$.pdf

General Statistics Office. (2015, 2016, 2017, 2018). Tổng múc bán lẻ hàng hóa và doanh thu dịch vu tiêu dùng giá thưc tế theo ngành kinh doanh Việt Nam 2015, 2016, 2017, 2018 [Total retail sales of goods and services at actual prices by business lines in Vietnam 2015, 2016, 2017, 2018]. Retrieved from https://www.gso.gov.vn/default.aspx?tabid=720

General Statistics Office. $(2015,2016,2017,2018)$. Tổng mức luu chuyển hàng hóa xuất nhập khẩu của Việt Nam 2015, 2016, 2017, 2018 [Total import and export flow of Vietnam in 2015, 2016, 2017 and 2018]. Retrieved from https://www.gso.gov.vn/default.aspx?tabid=720

Ha, D. (2010). Current situation and solutions to develop major logistics services in our country in international economic integration. Topic No. 15, under Subject of State-level Scientific Research: Developing logistics services in our country in the context of international economic integration, Code DTT 2010T / 33. Ha noi Institute of Economic Research and Development, National Economics University (Vn.).

Hai, P. (2019). Phát triển ngành dịch vu logistics tại Việt Nam [Developing logistics service industry in Vietnam]. Retrieved from http://tapchitaichinh.vn/nghien-cuu-trao-doi/phat-trien-nganh-dich-vu-logistics-tai-viet-nam-306129.html

Hue, B. (2019). Bùng nổ M\&A nghìn tỷ trong ngành logistics Việt [M\&A boom in trillion Vietnamese logistics industry]. Retrieved from http://vneconomy.vn/bung-no-ma-nghin-ty-trong-nganh-logistics-viet-20191122224330064.htm

Huong, T. (2009). Developing logistics system on the East-West economic corridor. Ministry-level Scientific Research Project, Code B2009 - 08 - 58. Ha noi, Foreign Trade University (Vn.).

Japan International Cooperation Agency (JICA) and Vietnam Ministry of Transport. (2010). Nghiên cứu toàn diện về phát triển bền vũng hệ thống giao thông vận tải ở Việt Nam (VITRANSS 2) [Comprehensive study of sustainable development of transportation system in Vietnam (VITRANSS 2)]. Retrieved from https://openjicareport.jica.go.jp/pdf/12000089.pdf

Jose L. T. (2018). Regulatory challenges in the Philippine logistics industry. No. 2018-01 (March 2018). Regulatory challenges in the Philippine logistics industry.

Lam, T. (2011). Experience in developing logistics centers in some countries around the world and lessons for Vietnam. Ministry level scientific research project, Code B2010 - 08 - 68. Ha noi Foreign Trade University (Vn.).

Linh, V., \& Hoai, N. (2019), Một số bất cập và giải pháp hoàn thiện pháp luật Việt Nam về dịch vu logistics [Some inadequacies and complete solutions of Vietnam's law on logistics services]. Retrieved from http://www.tapchicongthuong.vn/bai-viet/mot-so-bat-cap-va-giai-phap-hoan-thien-phap-luat-viet-nam-ve-di ch-vu-logistics-65172.htm

Linh, D. (2019). Logistics Việt Nam đang đi ngượ thế giới [Logistics Vietnam is going against the world]. Retrieved from http://vneconomy.vn/logistics-viet-nam-dang-di-nguoc-the-gioi-20191123124855516.htm

Loi, M. (2018). Co hội và thách thức cho ngành dịch vu logistics Việt Nam trong bối cảnh hội nhập sâu [Opportunities and challenges for Vietnam's logistics service industry in the context of deep integration]. Retrieved from http://www.tapchigiaothong.vn/co-hoi-va-thach-thuc-cho-nganh-dich-vu-logistics-viet-nam-trong-boi-canhhoi-nhap-sau-d55882.html

Mauro, V., Roberto, S., \& Fernando, B. (2012). Improving logistics services through the technology used in fleet management. JISTEM J.Inf.Syst. Technol. Manag., l.9(3). São Paulo Sept. /Dec. 2012. https://doi.org/10.4301/S1807-17752012000300006

Ministry of Industry and Trade. (2017). Báo cáo logistics Việt Nam 2017 logistics: Tù kế hoạch đến hành động [Vietnam logistics report 2017 logistics: From planning to action]. Retrieved from http://www.logistics.gov.vn/upload/bao\%20cao\%20logistics\%20viet\%20nam\%202017.pdf 
Ministry of Industry and Trade. (2018). Báo cáo logistics Việt Nam 2018 logistics thuoong mại và điện tủ [Vietnam logistics report 2018 commercial and electronic logistics]. Retrieved from https://www.slideshare.net/Goldtrans/bo-co-logistics-vit-nam-2018

Ministry of Industry and Trade. (2019). Báo cáo logistics Việt Nam 2019 logistics nâng cao giá trị nông sản [Vietnam logistics report 2019 logistics enhances the value of agricultural products]. Retrieved from https://gosmartlog.com/wp-content/uploads/2019/12/Bao-cao-logistics-viet-nam-2019.pdf

Ministry of Industry and Trade. (2019). Tài liệu huớng dẫn về chỉ số hiệu quả logistics (LPI) [Vietnam logistics report 2018 commercial and electronic logistics]. Retrieved from https://moit.gov.vn/documents/20182/26522/Tai+lieu+huong+dan+chi+so+LPI.pdf/dd68605d-b1ab-4b17-b 35b-11f18268864e

National Assembly of Socialist Republic of Vietnam. (2005). Commercial law. Ha noi National Political Publishing House (Vn.).

Nhung, P. (2019). Xu huoóng phát triển logistics tại Việt Nam trong Cuộc cách mạng công nghiệp 4.0 [Trends in logistics development in Vietnam during the 4.0 Industrial Revolution]. Retrieved from https://www.vnba.org.vn/index.php?option=com_k2\&view=item\&id=10070:xu-huong-phat-trien-logistics-t ai-viet-nam-trong-cuoc-cach-mang-cong-nghiep-40\&lang=vi

Quan, V. (2018). Tình hình các doanh nghiệp trong lĩnh vục Logistics tại Việt Nam [Situation of enterprises in Logistics field in Vietnam]. Retrieved from

https://dangkykinhdoanh.gov.vn/vn/tin-tuc/599/4868/tinh-hinh-cac-doanh-nghiep-trong-linh-vuc-logistics-t ai-viet-nam.aspx

Quang, D. (2014). Logistics Việt Nam: Thời kỳ rộng mở [Vietnam Logistics: An open period]. Retrieved from http://tapchitaichinh.vn/nghien-cuu-trao-doi/logistics-viet-nam-thoi-ky-rong-mo-72124.html

R. Glenn, R., Haozhe, C., \& Stanley E. F. (2009). The Moderating Role of Barriers on the Relationship Between Drivers to Supply Chain Integration and Firm Performance. International Journal of Physical Distribution \& Logistics Management, 39(10), 826-840. https://doi.org/10.1108/09600030911011432

R. Glenn, R., Anthony, R., Judith, W., \& Stanley, E. F. (2010). Exploring a Governance Theory of Supply Chain Management: Barriers and Facilitators to Integration. Journal of Business Logistics, 31(1), 237-256. https://doi.org/10.1002/j.2158-1592.2010.tb00137.x

Raja, I., \& Muhammad, I. (2014). Levels \& Barriers to Supply Chain Integration: Conceptual Model of Supply Chain Performance. International Journal of Management Science and Business Administration, 1(1), 52-59. https://doi.org/10.18775/ijmsba.1849-5664-5419.2014.11.1005

Ronald, H., Stephen, M., \& Ashok, M. (2000). New Managerial Challenges from Supply Chain Opportunities. Industrial Marketing Management, 29(1), 7-18. https://doi.org/10.1016/S0019-8501(99)00107-8

Stanley E. F., Matthew W., \& Gregory M. (2008). Supply Chain Alliances and Social Dilemmas: Bridging the Barriers That Impede Collaboration. International Journal of Procurement Management, 1(3), 318-341. https://doi.org/10.1504/IJPM.2008.017528

Thanh, N. (2019). 2 xu thế chủ đạo trong phát triển logistics Việt Nam [2 key trends in Vietnam's logistics development]. Retrieved from https://haiquanonline.com.vn/2-xu-the-chu-dao-trong-phat-trien-logistics-viet-nam-115772.html

Thai, N., \& Nhan, A. (2011). Business Logistics Management curriculum. Ha noi, Statistical Publishing House (Vn.).

The World Bank. International LPI. Retrieved from https://lpi.worldbank.org/international

Thuy, N. (2009). Port logistics concept and model. No. 17 - 4/2009. Journal of Science and Technology (Vn.).

Trang, T. (2018). Pháp luật Việt Nam về dịch vu Logistics trong hoạt động thuong mại điện tủ [Vietnam's law on logistics services in e-commerce activities]. Retrieved from

http://lapphap.vn/Pages/tintuc/tinchitiet.aspx?tintucid=207414

Tuong, N., \& Khoa, D. (2018). Cần có sụ hiểu biết dúng về logistics performance Index (LPI) [Proper understanding of logistics performance Index (LPI) is needed]. Retrieved from https://www.vla.com.vn/can-co-su-hieu-biet-dung-ve-logistics-performance-index-lpi.html

Uyen, P. (2019). Lương ngành logistics hàng nghìn USD mỗi tháng vẫn khó tuyển nguời Nam [Logistics salary 
thousands of dollars per month is still difficult to recruit people]. Retrieved from https://www.msn.com/vi-vn/money/news/1\%C6\%B0\%C6\%A1ng-ng\%C3\%A0nh-logistics-h\%C3\%A0ng-n gh\%C3\%ACn-usd-m\%E1\%BB\%97i-th\%C3\%A1ng-v\%E1\%BA\%ABn-kh\%C3\%B3-tuy\%E1\%BB\%83n-n $\mathrm{g} \% \mathrm{C} 6 \% \mathrm{~B} 0 \% \mathrm{E} 1 \% \mathrm{BB} \% 9 \mathrm{Di} / \mathrm{ar}-\mathrm{AABrgfQ}$

Uyen, T. (2018). Logistics service enterprises are both lacking and weak [Logistics service enterprises are both lacking and weak]. Retrieved from

http://thoibaotaichinhvietnam.vn/pages/kinh-doanh/2018-11-09/doanh-nghiep-dich-vu-logistics-vua-thieu-v ua-yeu-64104.aspx

Van, D. (2003). Logistics - The basics. Ha noi, Labor - Social Publishing House. (VN).

Vietnam Logistics Service Business Association (VLA) and Vietnam Logistics Research and Development Institute (VLI). (2019). Báo cáo ngắn về hiện trạng và đề xuất phát triển nguồn nhân lưc cho ngành logistics Việt Nam [Short report on current situation and human resource development proposal for Vietnam logistics industry]. Retrieved from

http://australiaawardsvietnam.org/images/Publications/2.-Bao-cao-ngan-ve-thuc-trang-nhan-luc-nganh-logis tics-2019.pdf

Vietnam National Shipping Lines. (2019). Cảng biển Việt Nam phát triển mạnh sau hai thập kỉ qui hoạch [Vietnamese seaports flourished after two decades of planning]. Retrieved from http://vinalines.com.vn/vi/cang-bien-viet-nam-phat-trien-manh-sau-hai-thap-ky-quy-hoach/

\section{Copyrights}

Copyright for this article is retained by the author(s), with first publication rights granted to the journal.

This is an open-access article distributed under the terms and conditions of the Creative Commons Attribution license (http://creativecommons.org/licenses/by/4.0/). 